conference from 1969 to 1971 and who is now with a pro-arms control group called the Committee for National Security, says that although the Soviets are clearly making political hay out of the proposal, it is nonetheless more than just words if experience is any guide. "They know that if they make a statement like this, they will eventually be called on it", he says.

Stephen Budiansky

French universities

\section{More change}

Paris

The French universities are to be reformed - again. A couple of years ago, the then President Giscard D'Estaing's minister of universities, Mme Alice Saunier-Seïté, set about the universities with a hatchet, amputating this and that to academic screams of "Fascist!" and worse. But now, more quietly and more carefully, the present socialist government of France is setting about a similar task. According to present analysis, Mme Saunier-Seïté was right about many things - it was only her draconian methods that were wrong.

The socialist idea is to base change on a 130-point questionnaire sent out a few months ago to presidents of universities, engineering schools and other such establishments by $\mathbf{M}$. Claude Jeantet, cabinet member at the ministry of national education. The questionnaire was very farreaching: it encouraged respondents to redefine the role of higher education in France. Jeantet has just analysed the results of that questionnaire - and he will use them to prepare the text of a new law on French higher education for his minister, M. Alain Savary. The new law is promised for the autumn. Although Jeantet will not publish the figures until then, it is already emerging that the government's task will be aided by a remarkable and sudden change in social outlook in the universities - one that has surprised even Jeantet. Now, university staff, often regarded in France as left-wing, see the government and even industry as partners, rather than enemies as appeared to be the case under Giscard d'Estaing. Now, it seems from the questionnaire, the universities are ready to forge links with industry and to run more courses aimed at training students for productive employment - an area in which they have previously been weak. It seems that one remnant of the 1968 university rebellion a horror of the market-place, and of all government control - is being replaced by a nationalistic commitment to help France escape from the present economic crisis. According to Alain Geismar, one of the revolutionaries of 1968 and now vicepresident of the University of Paris VII, the universities are now preparing to consider the provision of continuing education, post-retirement courses and science shops on the Netherlands model.

\title{
Argonne prepares for change
}

\section{Washington}

Argonne National Laboratory is renouncing a 16-year old agreement with a consortium of some 30 universities that has governed the laboratory ever since its principal machine, the Zero Gradient Synchrotron (ZGS), was built.

The laboratory outside Chicago is one of several, large, multipurpose energy laboratories whose fate is being deliberated by the White House and the Energy Research Advisory Board of the Department of Energy (DoE) (see Nature 6 May, p.3). Rumours that Argonne was to be closed helped prompt the move to change and streamline the laboratory's management. The ZGS itself was turned off a few years ago, leaving the laboratory to carry out other energy studies and nuclear physics, as well as some biology and other basic research.

Back in the heyday of building machines for high-energy physics, many colleges in the middle of the country wanted to have a big machine. When it was decided to put it near Chicago, a compromise was effected, in which other universities in the region could make input, and help get their scientists onto the machine, through a management group, the Argonne Universities Association (AUA). AUA's main job was

Behind a broad willingness to change in the universities, however, a number of difficult issues lurk. For example, one of the hottest and perhaps most important for French science is the reform of the French PhD system, presently a two-step exercise which is both weaker and stronger than an American PhD. The weak step is the more contentious: the troisième cycle (essentially a two- or three-year MSc course). A good result in the troisième cycle is enough to get a graduate an effectively tenured post as a researcher (assistant at a university, or attaché in a government laboratory). The second step - the major thesis, leading to a doctorat d'état - can take seven years.

Science minister Jean-Pierre Chevènement's law for research and technology, in its present form, contains a commitment to change the system, but no details about how it is to be done; that is up to Jeantet and Savary.

Tenure is, however, a very closely regarded right in France, and the unions, whose influence over the government is strong, will defend it vehemently. One University of Paris professor, whose leftwing leanings combined with a desire to see France do good research perhaps make him typical, said last week that he was "schizophrenic" over the issue. The French system leaves a large pool of relatively untalented researchers at work in France, half of whom would not be in research if they were in the United States.

Robert Walgate to coordinate the high-energy physics programme at Argonne, but it also had management responsibility in other areas. The University of Chicago was also involved in management, through a tripartite agreement involving the university, AUA and DoE, which provides 90 per cent of the laboratory's budget of $\$ 200$ million.

Without the ZPG, however, there is no need for regional high-energy physics coordination at Argonne. As one scientist formerly at the laboratory says, the AUA structure is also potentially divisive, allowing almost anyone who wants to do something to Argonne to get into the act.

So Argonne's management will gradually be streamlined. AUA will bow out and the University of Chicago will become the manager. Regional universities can still participate through an advisory steering committee. DoE will continue to fund the laboratory.

The laboratory seems unlikely to go out of business, according to DoE, but it may be substantially redirected. For instance, Senator Charles Percy wants to bolster the laboratory's flagging mission by transferring civilian research activities now at Los Alamos and Livermore laboratories to Argonne.

Deborah Shapley

\section{Franco-Soviet space-flight}

\section{Up and away}

The space-flight of the Frenchman JeanLoup Chrétien, the first West European in orbit, has been hailed as a triumph for detente and cooperation in both France and the Soviet Union. Although events in Poland had moved a number of French scientists to sign petitions advocating withdrawal from the flight, the Centre National d'Etudes Spatiales (CNES) says that Chrétien's is merely the logical next step in a cooperation programme that has been flourishing for fifteen years.

The coincidence of Chrétien's flight and the final test-run of the US shuttle prompted Le Monde to draw a contrast between the French approach and the "cold-war" aspects of Columbia. (The fact that, in spite of frequent official denials, the Soviets also appear to be working on a shuttle with, presumably, a similar military potential, was overlooked.)

In their run-up to the flight, the French have exercised considerable tact, even coining the word "spacionaute" to avoid using either the American or the Russian terminology. In return, the Soviet side has permitted a degree of openness about the preparations for the flight that has not been seen since the preparations for the SoyuzApollo flight in 1975. While some of this 
must have been unavoidable, some revelations seem to have been made purely as an exercise in détente. Five days before the flight, for example, Professor Igor Konstantinovich Bazhinov, the deputy chief of flight ballistics, admitted on Moscow radio that Salyut -7 had undergone unexpected orbital drift, and that a special correction had been necessary to ensure the successful docking of the "international" crew - a degree of intimacy with his audience that is unusual by Soviet standards.

The French experimental programme for the flight was, in fact, outlined in the CNES annual reports for 1980, and includes sensory physiology (including the vestibular, visual and kinaesthesic systems) and the effects of soft radiation on the developmental capacities of unicellular and multicellular organisms. The biological experiments are a continuation of previous Franco-Soviet work using unmanned probes.

Little has been said, however, about the type of space station to be visited by the "spacionaute". Although all CNES releases spoke cautiously of a "Salyut" station, without giving it a number, they were illustrated by a schematic diagram of Salyut-6. Only after the launch this spring of Salyut-7 was it stated that Chrétien would pass his historic week in space aboard what the Soviets say is a more advanced and more confortable space station.

Vera Rich

\section{French science $l o i$}

\section{Who will lose? \\ Paris}

The long-awaited French law for science and technology, which guarantees a 17.8 per cent annual real growth in government civil research spending until 1985, is now almost on the statute books. At present, it lies under the harsh light of an inter-house committee of the French Parliament, which is attempting to reconcile the differences between the views of the Senate (which all but overturned the law) and the Assembly (which supported it). Second readings are to take place next week but it appears that the law will sail through much as planned by $\mathbf{M}$. Jean-Pierre Chevènement and his team, even if those most affected will be reading its provisions with a magnifying glass to see exactly what has, and what has not, been left in.

One thing that was left out is causing the more cautious of French scientists to pause for thought. The law is divided into three sections: an introduction, the law proper (which is quite short) and an annexe. The full force of law attaches only to the law proper, so one question has been what is to go into the law, and what into the annexe? In the research ministry version, fundamental science is mentioned only in the annexe - where there is talk of 13 per cent growth (less than the 17.8 per cent total growth, reflecting the fact that the Chevènement plan mostly concerns technology). Some deputies at the Assembly, briefed by university researchers, pushed for the 13 per cent to be inscribed into the law proper, but the government refused.

Does this mean that basic research is going to be less well protected against the current French financial crisis than technology? Some French scientists fear so. The question is how far should Chevenement's technological imperatives, outlined in seven major investment programmes from space to biotechnology, encroach on and influence the whole of science. It is beginning to look as if they will be very pervasive.

For example, new accounting methods are to be applied to the big government research organizations, such as the Centre National de la Recherche Scientifique (CNRS), which means that they will be controlled from the ministry, programme by programme, rather than by total budget. The organizations will also be given explicit new tasks, such as the application of their research to profitable ends.

Even the small protection given to basic science by the ministry of national education may be being eroded, as the ministry appears to be adopting the same priorities as the ministry of research. (In distributing its research money, which amounts to perhaps a fifth of the total obtained by universities, the ministry of national education recently asked universities to favour groups already supported through the ministry of research and technology.)

Nevertheless, the fears may be misplaced if French research is compared with the situation of research in other countries. If the 13 per cent figure is respected - and ministry of research officials insist that although only in the annexe, the figure has force - French scientists will be doing far better than their foreign colleagues. For the sum includes a 4.5 per cent annual increase in the number of salaries, and salaries amount to more than two-thirds of basic research costs. The result is that next year's true research budget - what a laboratory director will have in his pocket to spend would be up by more than 25 per cent in real terms, an increase so large that one senior researcher said last week that it would be "frankly a problem" working out how to spend the money.

For the ministry, the next problem will be how to raise the money promised, against a sombre French economic background (although the promised figures are only averages to 1985) and then how to put into effect certain structural changes outlined in the law. Not least of these is the reform of CNRS and related organizations which will be given new statutes allowing them to make profitable links with industry. CNRS will also get new rules for electing its internal review body, the Comite National. These new rules are themselves contentious. It appears that the Comite will exclude university lecturers not at present or previously associated with the organization, thus, according to some, deepening the rift between the universities and CNRS.

Robert Walgate

Laboratory animal welfare

\section{Congress in sight of compromise}

\section{Washington}

After months of negotiation between animal welfare groups and representatives of the biomedical research community, a bill that would tighten up standards for the treatment of laboratory animals has reached the House of Representatives Science and Technology Committee.

This compromise proposal (HR 6245) is now the only serious contender among the several animal welfare bills filed with the House. It will be taken up by the committee later this month when the House returns from its Independence Day recess. The bill avoids some of the extreme measures that some animal groups had pressed for, such as setting aside up to 50 per cent of the National Institutes of Health (NIH) funds now going to work involving animais used for research into non-animal substitutes. But it would impose strict requirements on the care of animals used in federallysupported research. Researchers would have to justify any distress caused to a research animal and ensure that pain was minimized (through the use of tranquillizers and anaesthetics, for example). No animal could be used in more than one major operative procedure, except in special circumstances.

The legislation grew out of hearings held last autumn by a House subcommittee in response to considerable public pressure. At that time legislation for the protection of laboratory animals was not serving the interests of anyone very well. Under the present law, the Animal Welfare Act of 1966, the responsibility for enforcement falls on the Department of Agriculture (USDA), which critics say is understaffed and cannot do a proper job.

Last autumn, for instance, USDA inspectors found only minor violations in Dr Edward Taub's laboratory just weeks before he was indicted under Maryland's animal cruelty law for causing pain and suffering to monkeys. Although Dr Taub protested that he was the victim of a public relations stunt by a group called People for Ethical Treatment of Animals, which had infiltrated one of its members into $\mathrm{Dr}$ Taub's Institute for Behavioral Research in Silver Spring, Maryland, he was convicted of the charges and also had a $\$ 200,000$ NIH grant taken away from him. Dr Taub appealed against the conviction, and his case is now being heard.

In an effort to obtain the widest possible support for new legislation, the subcom- 